\title{
SUMMER BOOKS
}

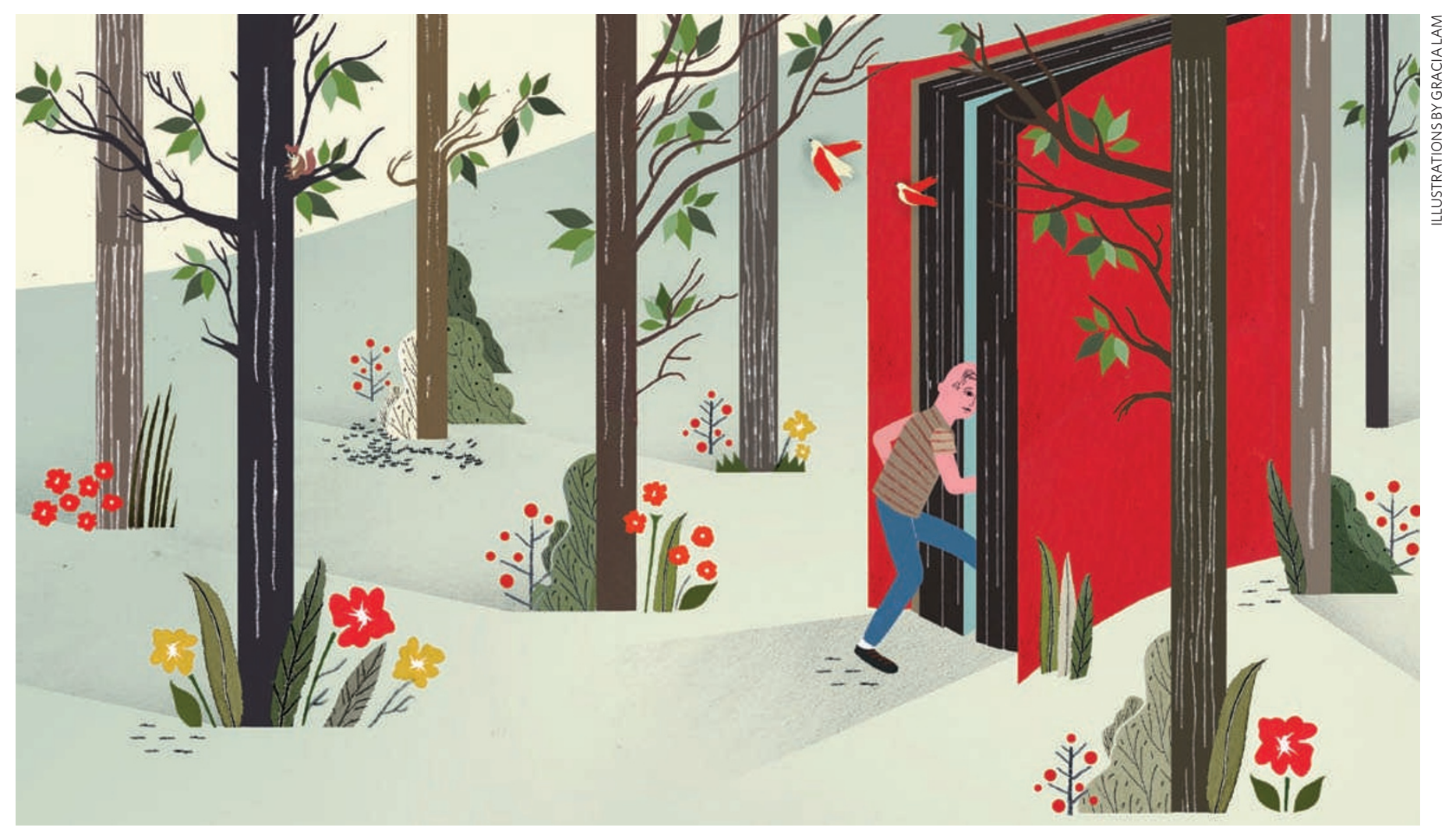

\section{Vacation reading}

Recent reviewers suggest good books to refresh your mind this summer - from a cultural history of piracy to a scientific tour of the boulevards of Paris.

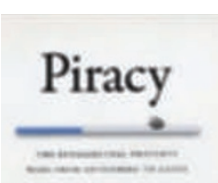

doween peses
STEVEN SHAPIN

Piracy: The Intellectual

Property Wars from Gutenberg to Gates by Adrian Johns

University of Chicago Press: 2010.

Scientific and technological pirates are villains. They steal property rights from legitimate authors or inventors, drain the forces of innovation from society and prevent people from benefitting from new ideas and products. Yet from another point of view, pirates are heroes - freeing ideas and artefacts from the strangleholds of monopolies and restrictive regimes, ensuring their spread and nourishing creativity. If we want innovation, we should have more piracy, not less.

Adrian Johns's learned and witty book Piracy is much more valuable than yet another polemic about modern property rights in science and technology. It is a compelling cultural history of the paired ideas of piracy and property from the seventeenth century to the present, showing how the notion of piracy lies right at the heart of what we think science and technology are. The best history takes readers from a familiar present to a strange past, and delivers them back to a present that can be seen in new ways. Piracy is that sort of history.

Steven Shapin is professor of the history of science at Harvard University, Cambridge, Massachusetts.

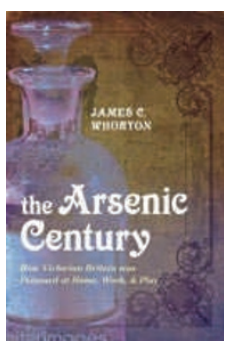

\section{W. F. BYNUM}

The Arsenic Century:

How Victorian Britain was Poisoned at Home, Work, and Play by James $\mathrm{C}$. Whorton Oxford University Press: 2010

James Whorton's book is the latest of several paeans to arsenic. The 33rd element in the periodic table surrounded our forebears in the nineteenth century. Its compounds were used in making wallpaper and paint; formed active ingredients in popular medical remedies; were beloved by ladies wanting a pale complexion and men seeking potency; and had many industrial and agricultural uses, including sheep dipping.

Arsenic trioxide - which the Victorians called arsenious acid or white arsenic - was also a cheap and readily available rat poison. Unsurprisingly, it was commonly used in suicide and murder. Whorton's entertaining monograph recounts these and many other aspects of arsenic's Victorian history. He has an eye for gory detail and describes many famous trials, looking at the rise of forensic toxicology and the expert scientific witness. Victorian concern with arsenic's dangers resulted in legislation, which played a part in early environmental awareness. As well as opening up vistas of Victorian science, medicine and society, The Arsenic Century is a good read.

W. F. Bynum is emeritus professor of the history of medicine at University College London. 


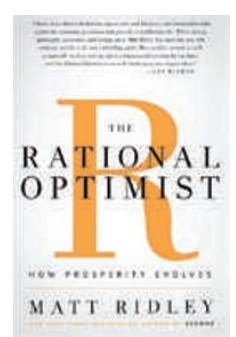

\section{MICHAEL SHERMER \\ The Rational Optimist: How Prosperity Evolves by Matt Ridley \\ HarperCollins: 2010.}

Take a break from economic woes by reading The Rational Optimist. We've never had it so good, according to Matt Ridley, who sees the current financial crisis as just a blip in human evolutionary history. In the long run, he argues, trade has ensured that our lives keep getting better. And there is no inevitable end to those improvements. "Exchange is to cultural evolution as sex is to biological evolution," he writes.

The more we have diversified as consumers and specialized as producers, the better off we've become; and the more people who are engaged in trading, the wealthier we will all be. In the teeth of the recession and with millions of impoverished people in developing countries today, his thesis sounds ripe for scepticism. But Ridley builds a solid case through copious data. He shows that most of us are better fed, sheltered, entertained, protected against disease and more likely to live to old age than our ancestors. We have greater access to "calories, watts, lumen-hours, square feet, gigabytes ... and of course dollars" than any that went before.

Michael Shermer is editor of Skeptic magazine. that the errors that we make are surprisingly systematic. We don't plan how to be happy; we stumble on it, thanks to a bit of enthusiastic serendipity.

Nicky Clayton is professor of comparative cognition at the University of Cambridge, UK.

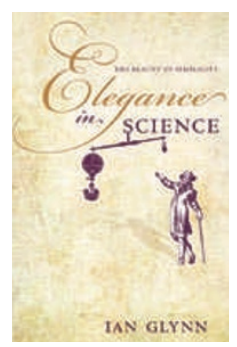

\section{SERGE DAAN}

Elegance in Science: The Beauty of Simplicity by lan Glynn Oxford University Press: 2010.

Elegance in Science is an erudite book. Physiologist Ian Glynn — who has charmed us before with his lucid writing in An Anatomy of Thought (Oxford University Press, 2000) - steps beyond his field to share his interest in the broad enterprise of science. He describes elegant theories, proofs, explanations and experiments that have marked important breakthroughs, from Pythagoras's theorem through Faraday's demonstration of electromagnetic induction to the unravelling of the genetic code. Elegance, he argues, is easily recognized but it is no guide to truth. Well illustrated and full of historical anecdote and background, this is an elegant volume indeed.

Serge Daan is professor of behavioural biology at the University of Groningen, the Netherlands.

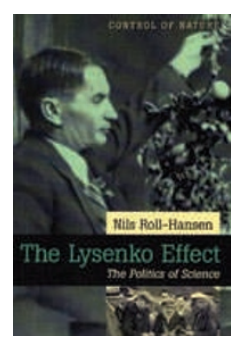

HANS VON STORCH The Lysenko Effect: The Politics of Science by Nils Roll-Hansen Humanity Books: 2004 The story of Soviet agrobiologist Trofim Lysenko (1898-1976) is still relevant today. A leading scientist during Josef Stalin's dictatorship, Lysenko has attracted much criticism, from being accused of hindering the progress of Soviet biology to being involved in the deaths of scientists under the regime. It is said that he rose to the top largely because of political support: his biological ideas of genetic inheritance fitted with the Stalinist social ideology of the day. But it is not so simple, according to Nils Roll-Hansen, a historian of science of the Norwegian Academy of Science and Letters.

In The Lysenko Effect, he argues that Lysenko's rise was warranted on the basis of his scientific research, which was backed by others both within the state and overseas. Only later did the political utility of those ideas come to dominate. Roll-Hansen's account provides a good example of how the dynamics of science can become corrupted when stakes are high and knowledge is uncertain. Now, when a dispassionate discussion is possible, Lysenko's story holds lessons for the configurations of socially important sciences. These include the need to maintain politically neutral and impartial review processes.

Hans von Storch is director of the Institute of Coastal Research, GKSS Research Center Geesthacht, Germany.

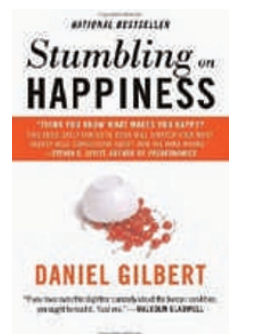

NICKY CLAYTON Stumbling on Happiness by Daniel Gilbert Harper Perennial: 2007.

It is often argued that the human ability to imagine our personal future is what distinguishes us from other animals. We also spend a lot of time agonizing over our plans, as conveyed by Mark Twain: "I have been through some terrible things in my life, some of which actually happened." Yet humans are remarkably bad at looking forward. In Stumbling on Happiness, psychologist Daniel Gilbert explains why this is so, drawing on a range of disciplines from cognitive neuroscience and psychology to philosophy and behavioural economics. He describes how our brain imagines its future, how its predictions of which scenarios we shall enjoy are poor, and thus why we are so unreliable at forecasting our future selves. He also reveals
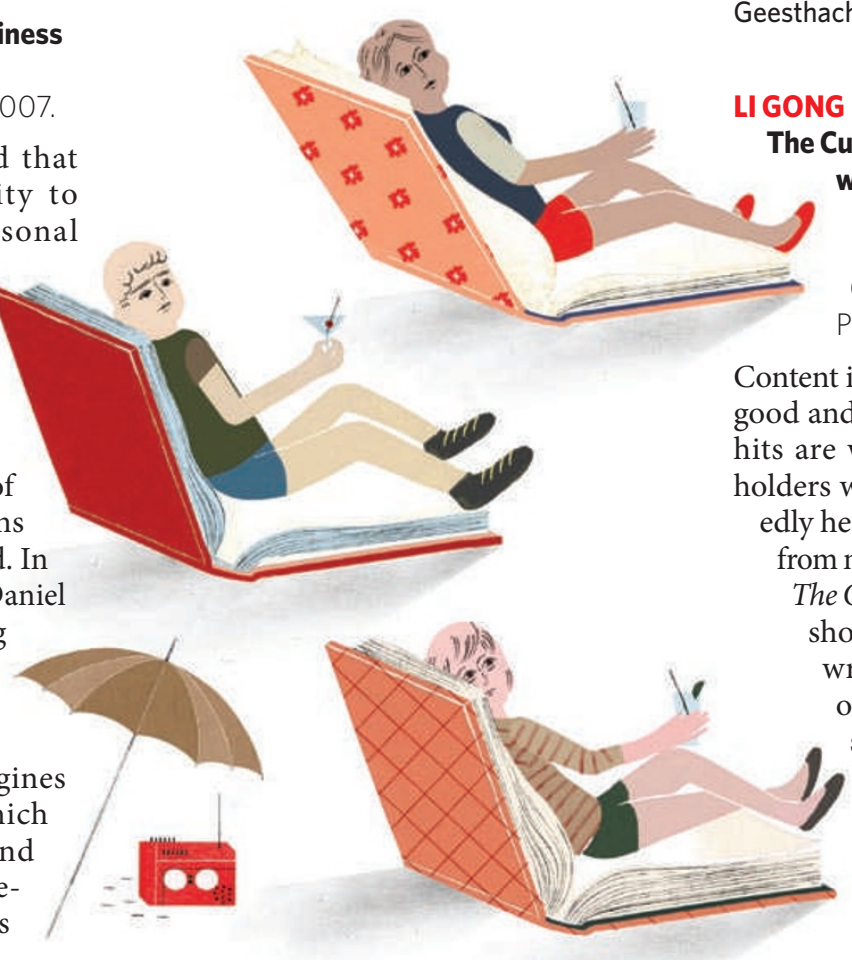

Content is king, growth is good and celebrity-based hits are what the shareholders want. We repeatedly hear these mantras from media leaders, but The Curse of the Mogul shows that they are wrong. Providers of glamorous material — such as film studios and magazines - are consistently outperformed by more staid businesses such as printers and distributors. That is the conclusion of this startling analysis of media practices by these economists 
at Columbia Business School in New York. Backed by extensive data, the authors demonstrate that many content-producing companies seek glamour at the expense of shareholder value and maintain growth only through paying unjustifiably high prices for smaller rivals, and that the lion's share of their profits are accrued mainly by artists, agents and media executives. In the past decade, the book reveals, leading media companies have written off more than US $\$ 200$ billion in assets in this way. The Curse of the Mogul is sober reading for anyone interested in communications and business. Li Gong is chief executive of Mozilla China.

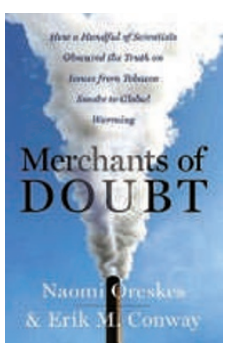

\section{DAVID ORR \\ Merchants of Doubt: How a Handful of Scientists Obscured the Truth on Issues from Tobacco Smoke to Global Warming \\ by Naomi Oreskes and \\ Erik M. Conway \\ Bloomsbury Press: 2010.}

Worse than yelling "Fire!" in a crowded theatre that is not ablaze is suppressing warnings if the theatre is indeed burning. Naomi Oreskes and Erik Conway's outstanding book, Merchants of Doubt, is the sorry history of manufactured denial, from defence of the tobacco industry to shrugging off the tsunami of climate destabilization that is about to break over our heads. It is a story of a group of once-capable scientists who were fuelled by corporate money, resentment and ideology to serve the fossil-fuel, chemical and tobacco industries. For decades, these players sowed public doubt and confusion to delay action on important issues facing humankind. In the case of climate change, their interventions have meant that we have squandered whatever margin for error we may once have had. We don't know whether this story will end in tragedy. But it is no longer just about science.

David Orr is professor of environmental studies and politics at Oberlin College, Ohio.

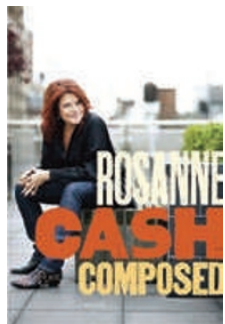

\section{DANIEL LEVITIN Composed: A Memoir} by Rosanne Cash Viking: 2010.

Whether in Nobel prizewinners or top musicians, the origin and development of expertise fascinates scientists and the public alike. Writing with an eye for detail and an open heart, singer-songwriter

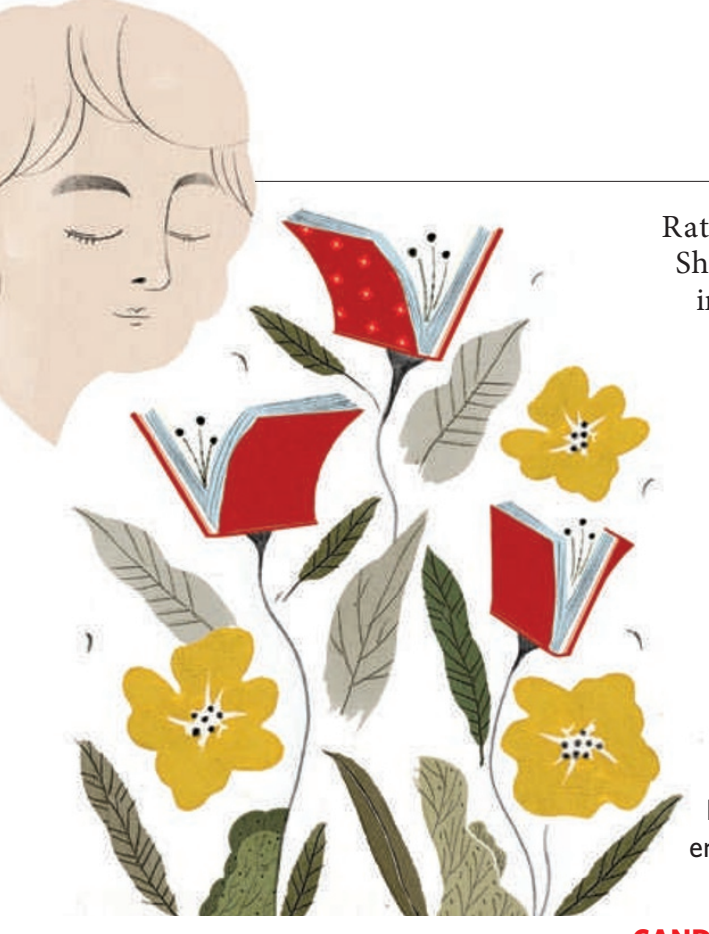

$r$ than focusing on measures of Shereshevsky's capacity for remembering, Luria asks what it is like to live with a boundless memory, giving a fascinating insight into the mechanisms of retention and importance of forgetting. The US psychologist William James argued in the nineteenth century that if we were able to remember everything, we would be as ill as if we remembered nothing. Shereshevsky too made desperate attempts to forget irrelevant information. Luria also writes of how great memory capacity leads to deficits in abstract thinking. More than 40 years later, his book remains a classic.

Rodrigo Quian Quiroga is a professor in bioengineering at the University of Leicester, UK.

Rosanne Cash offers insights into success in her eloquent memoir, Composed. After describing her childhood and lifelong quest to know her famous father Johnny Cash better, Rosanne reveals her struggles to create original songs and navigate the collisions of art and commerce that culminated in her gaining 11 number-one hits and a Grammy award.

Avoiding the constraints of her famous name, Rosanne has emerged as an authentic and distinct artist, her career representing the achievement of willpower and intellect over an industry fuelled by superficialities. Composed is an inspiring literary journey, a testimony to the power of song, love and human resilience. Although her sufferings and triumphs are her own, her insights into life's challenges are universal.

Daniel Levitin is a professor in the Department of Psychology, McGill University, Montreal, Quebec, Canada.

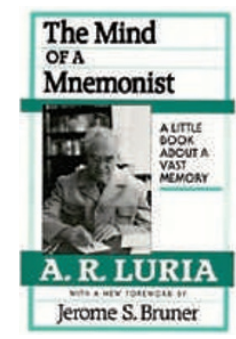

\section{RODRIGO QUIAN} QUIROGA

The Mind of a

Mnemonist: A Little Book About a Vast Memory

by Alexander

Romanovich Luria

Basic Books: 1968.

By effortlessly remembering long sequences of numbers and letters, Solomon Shereshevsky immediately made a deep impression on the young psychologist Alexander Luria. The Mind of a Mnemonist is a beautiful testimony to the relationship that built up between them, starting in the 1920s and stretching over three decades. As captivating as a novel, the book gives profound insight into the realms of memory.

\section{CANDIS CALLISON \\ Galileo's Dream}

by Kim Stanley Robinson

Harper Voyager: 2009.

In the novel Galileo's Dream, Kim Stanley Robinson weaves into the framework of Galileo Galilei's life story the craftsmanship of

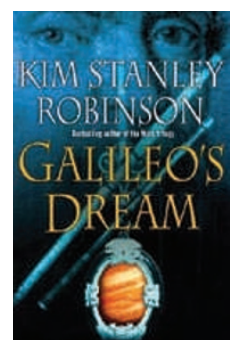

early telescope-making, the halls of Italian patronage in the seventeenth century and the moons of Jupiter in the year 3020. Robinson, whose intricate characterizations have been admired in his science-fiction Mars trilogy, makes the many paradoxes of Galileo come alive - as an artisan, tinkerer, political animal, Catholic, father, master and scientist. In opening up the genius and flaws of this famous character, the writer ruminates on the concepts of time, space and consciousness. He prompts us to reflect on broad topics from science and the state of the planet to the choices we make about our work and personal relationships.

Candis Callison is an assistant professor in the Graduate School of Journalism at the University of British Columbia, Vancouver, Canada.

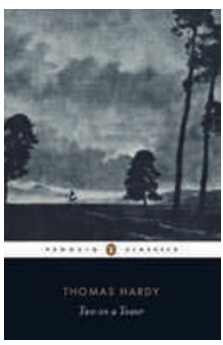

\section{JENNIFER ROHN} Two on a Tower by Thomas Hardy Penguin Classics: 2006 First published by Sampson Low: 1882.

Like many scientists, I vividly recall the first time I saw that my research had been scooped: opening a journal to find my unfinished work published by another group. A similar event 


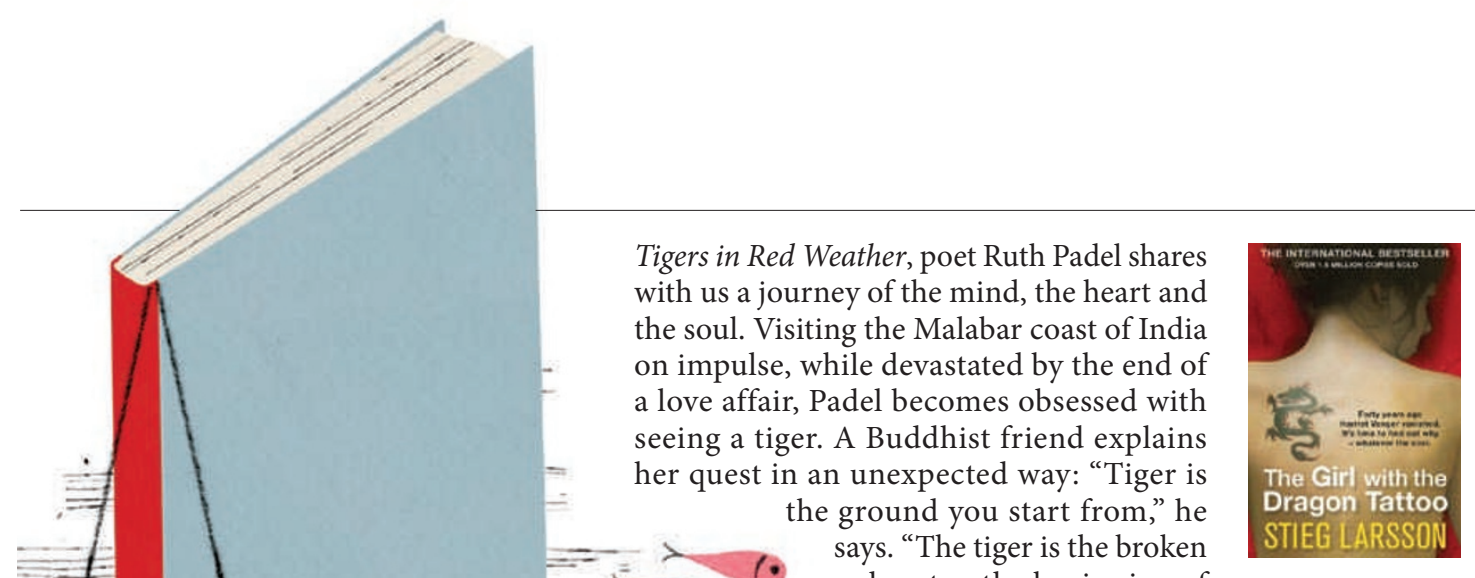

ABDALLAH DAAR The Girl with the Dragon Tattoo

\section{by Stieg Larsson}

MacLehose Press: 2008. The Girl with the Dragon Tattoo is a modern detective mystery that is solved partly by computer hacking. Stieg Larsson's heart ... the beginning of change ... the beginning of the journey."

Padel travels to Bangladesh, Bhutan, China, India, Laos, Nepal, Russia, Sumatra and Thailand, rarely glimpsing her quarry but learning about the conservation, politics and biology of tigers and exploring their impact on the cultures with which they live. She plods through sweltering jungles, climbs mountains, rides elephants, endures stiflingly decorous

befalls the protagonist of Thomas Hardy's 1882 novel Two on a Tower. Rather than simply retire to the pub after such a setback, as many of us would do, Hardy's romantic hero hurls himself into the damp heather and contracts pneumonia. Given that scientists as sympathetic central characters are rare in classic novels, it is a pleasure to follow Hardy's amateur astronomer as he tries to compete with scholarly teams on a pauper's salary. When the patronage of a rich woman provides him with a tower for observational vantage and cash for proper equipment - as well as a torrid affair - his career takes off.

Although later plot developments resemble the twists and turns of a beach-read romance, Hardy can be forgiven because his portrayals of the scientist are realistic. The tale is especially interesting because it is set in the period when science was transforming from armchair pastime to professional endeavour. Jennifer Rohn is a cell biologist at University College London and editor of LabLit.com.

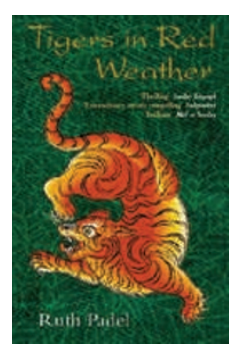

\section{PAT SHIPMAN} Tigers in Red Weather: A Journey Through Asia by Ruth Padel

Little, Brown and Company: 2005.

A good book takes you on an adventure and teaches you something too. In banquets, and sleeps in trains, rangers' huts and cheap hotels. Padel reveals the conflicts that make tiger preservation so difficult and the efforts of those who try so heroic.

Pat Shipman is a professor of biological anthropology at Penn State University, University Park, Pennsylvania.

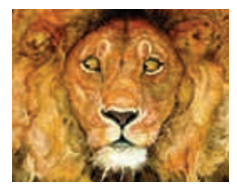

\section{JESSICA HELLMANN} The Lion and the Mouse by Jerry Pinkney Little, Brown and Company: 2009

Most of the biologists I know were inspired at a young age by the mysteries of nature. I hope that my 3-year-old daughter, too, will dream of fireflies, of walks through fields of wildflowers or of saving the last great places on Earth. Of the children's books that capture the wonders of untamed places, Jerry Pinkney's rendition of the classic Aesop fable, The Lion and the Mouse, is special. Set in the African savannah, Pinkney explores the beauty of creatures great and small, and the way that each contributes to the fabric of life. When the meek mouse saves the powerful lion from capture by hunters, every reader cheers the victory of nature over humanity. Even a seasoned scientist will remember the inspirations of childhood.

Jessica Hellmann is associate professor in conservation biology at the University of Notre Dame, Indiana. posthumous international best-seller centres on the search for a girl who has disappeared. Her wealthy great-uncle recruits a journalist to find her, with the help of the girl with the dragon tattoo - a withdrawn character who is a genius at computer hacking and a natural mathematician. The events surrounding the great-niece's disappearance are meticulously and ingeniously pieced together, with plenty of scientific insight.

Abdallah Daar is a professor of public-health sciences and of surgery at the University of Toronto, Ontario, Canada.

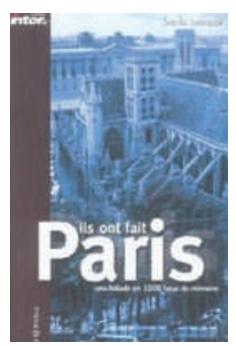

VACLAV SMIL Ils on fait Paris: Une balade en 1000 lieux de mémoire by Denis Lemarié Castor \& Pollux: 2004 (in French).

Ils on fait Paris celebrates the French capital as one of the world's great centres of intellectual accomplishment. The guide points out 1,000 memorable sites - streets, houses, statues, plaques and museums - connected with inventors, entrepreneurs, writers, composers and painters. The big scientific names are included, from Louis Pasteur's laboratory in the rue d'Ulm to Marie and Pierre Curie and their discovery of radium in rue Vauquelin.

But there are also traces of those who are now mostly forgotten. In 1817, chemists Pierre-Joseph Pelletier and Joseph Bienaimé Caventou discovered chlorophyll, and later quinine, in a house on the boulevard SaintMichel. In 1890, in another house on the same boulevard, physicist Edouard Branly made his coherer, a better detector of electromagnetic waves than Heinrich Hertz's spark-gap transmitter. In 1908, the pioneer aviator Henri Farman, whose eponymous rue is in the 15th arrondissement, flew Gabriel Voisin's biplane around the first one- and two-kilometre circuits. Paris: so many memories, so many accomplishments.

Vaclav Smil is a professor in the Faculty of Environment at the University of Manitoba, Winnipeg, Canada. 